\title{
Il Caravaggio a Messina: l'Adorazione dei Pastori, una tela da riscoprire
}

\author{
Mariateresa Galizia \\ Giuseppe Maria Spera
}

Abstract

La ricerca esamina l'opera del grande Michelangelo Merisi, detto il Caravaggio, realizzata durante il soggiorno siciliano. II dipinto, viene commissionato dal Senato di Messina e poi donato ai frati francescani cappuccini per ornare l'altare maggiore della chiesa di Santa Maria la Concezione del convento dei Cappuccini. Oggi si trova conservato presso il Museo regionale della città. L'iconografia nel dipinto è francescana e, dalla lettura critica dell'opera a posteriori in assenza di bozzetti preliminari, traspare la sensibilità del Caravaggio alle emozioni che i luoghi vissuti suscitano nella sua personalità irrequieta. L'attenzione dell'artista, agli usi e alle tradizioni della gente del luogo, è velata da quell'atmosfera luttuosa che pervade le sue ultime opere. Nella rappresentazione della scena l'artista connette, attraverso la rilettura di usi, tradizioni e materiali locali ('paglialore' siciliane), significati universali. Tramite lo strumento disvelatore del disegno, si è ipotizzato l'impiego da parte dell'artista di tracciati regolatori geometrici sottesi, che ordinano la composizione pittorica e che utilizzano, nella modularità che scandisce l'ambiente rappresentato, l'unità di misura meridionale (la canna e il palmo). Ulteriori considerazioni sono emerse dall'analisi della prospettiva centrale in cui il punto di vista disassato evidenzia il piano di profondità, consentendo di dare un maggiore spazio alla scena e quindi una maggiore nitidezza ai personaggi che la riempiono.

Parole chiave

Michelangelo Merisi, realismo, luce, prospettiva, tracciati regolatori.

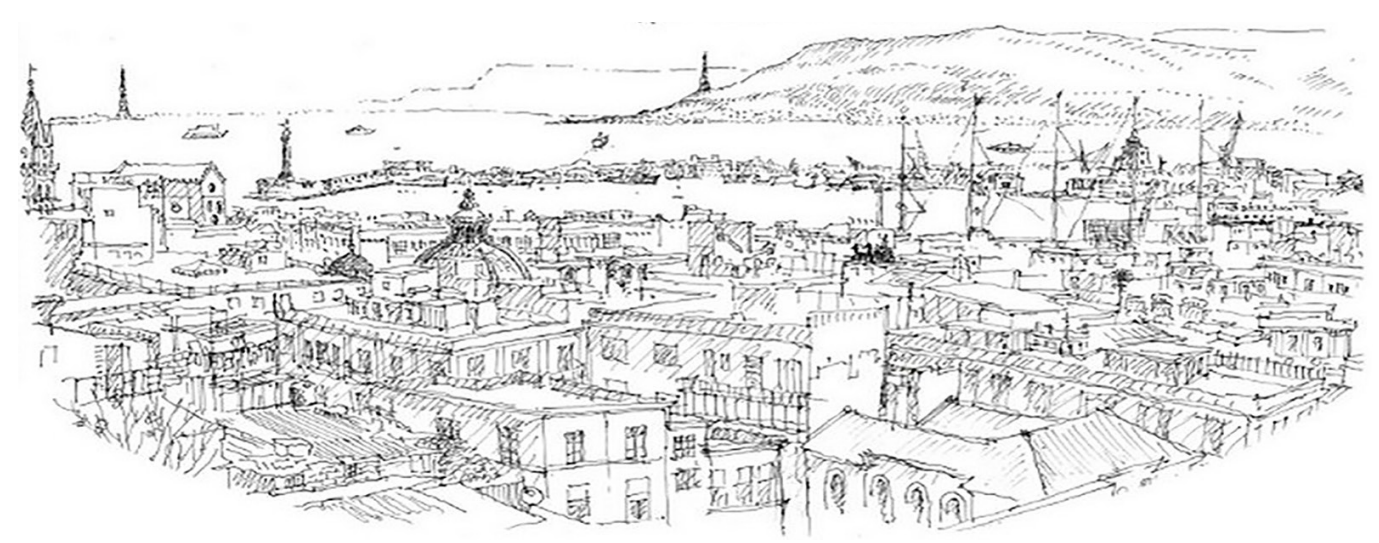




\section{Introduzione}

Lo stretto di Messina è stato nei secoli fonte di ispirazione di storie, miti e leggende, oltre ad essere stato testimone delle molteplici civiltà che sono giunte in Sicilia dai diversi continenti, e che hanno lasciato il loro sapere negli usi e costumi degli abitanti locali. Lo stretto e l'intera Isola hanno ricevuto da sempre le attenzioni delle civiltà più antiche - Greci, Romani, Arabi, Normanni e Spagnoli - che resero I'Isola un territorio multiculturale. Nei mari che lambiscono la Sicilia hanno viaggiato nomi importanti di eroi, letterati, artisti e uomini politici. Tra questi Michelangelo Merisi [I], detto il Caravaggio, che durante la sua permanenza siciliana non potè fare a meno di confrontarsi con suoni, odori, sapori, luci, ombre e colori tipici del panorama locale che si diversifica nettamente da quello che aveva lasciato a Roma o nella stessa Malta. L'artista, famoso per ritrarre nelle sue scene la veridicità delle esperienze quotidiane, l'ambiente vissuto, la gente comune con occhio libero privo di pregiudizi, sicuramente per le sue scene pittoriche prese in prestito dalla terra insulare materiali, tradizioni e costumi. Oggetto di studio del presente lavoro è una tela del Caravaggio intitolata la Adorazione dei pastori (fig. I) una delle due opere che l'artista eseguì nella città Peloritana. L'opera rappresenta la Natività povera interpretata attraverso il 'segno' che riesce a connettere e a combinare reinterpretando, le emozioni suscitate dai luoghi e dalle esperienze vissute. II dipinto venne commissionato nel 1609 dal Senato messinese per adornare l'altare maggiore della Chiesa di Santa Maria la Concezione [2], governata dai monaci cappuccini, oggi non più esistente [3] (fig. 2). Con l'ordine religioso il pittore ebbe reiterati contatti e rapporti che, nelle diverse tappe del suo soggiorno in Sicilia, si rinsaldarono e ravvivarono alimentati dalla condivisione di una intensa visione comune di spirito e di intenti (fig. 3).

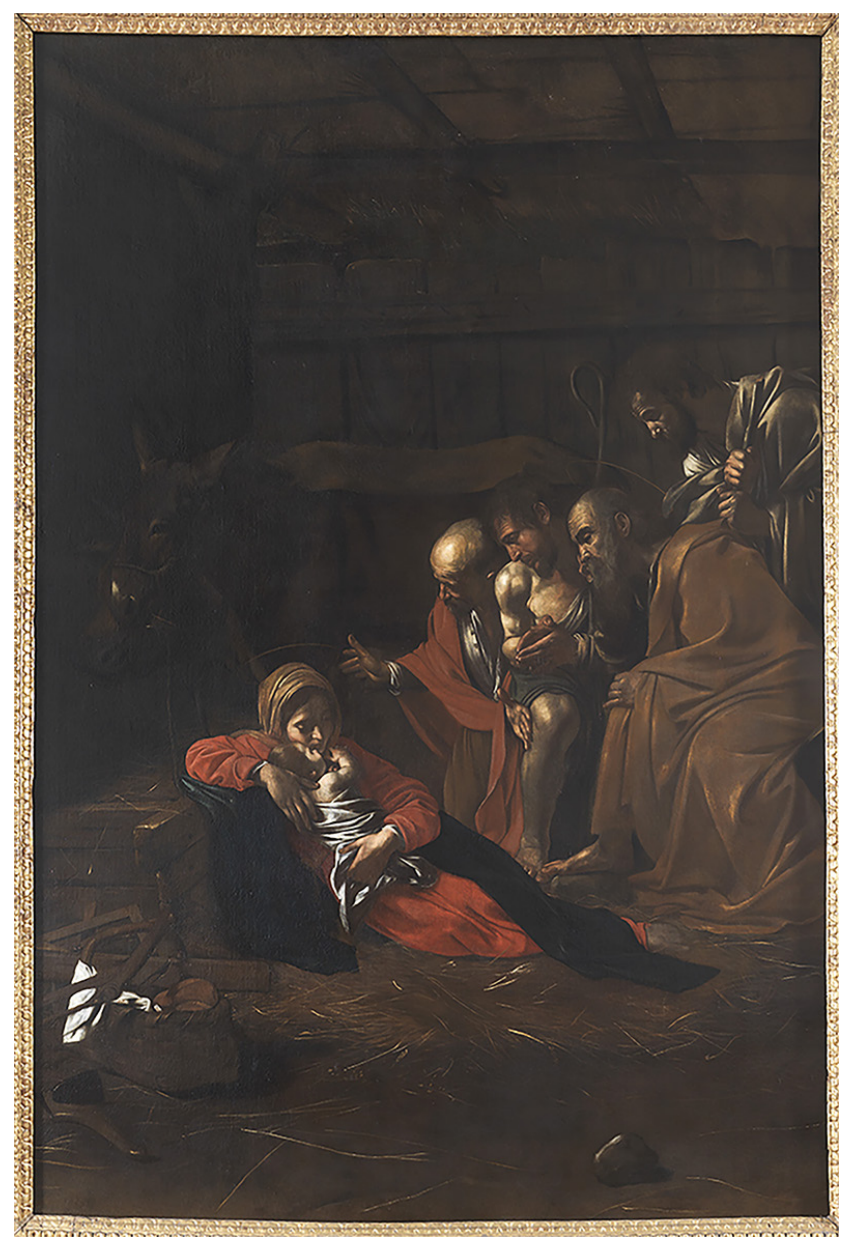


Fig. 2. Prospetto della Chiesa dei Cappuccini dopo il terremoto del 1908 (in G. Molonia Opere d'arte dei Cappuccini di Messina, a cura di G. Lipari, Messina 2015 pag. 239).

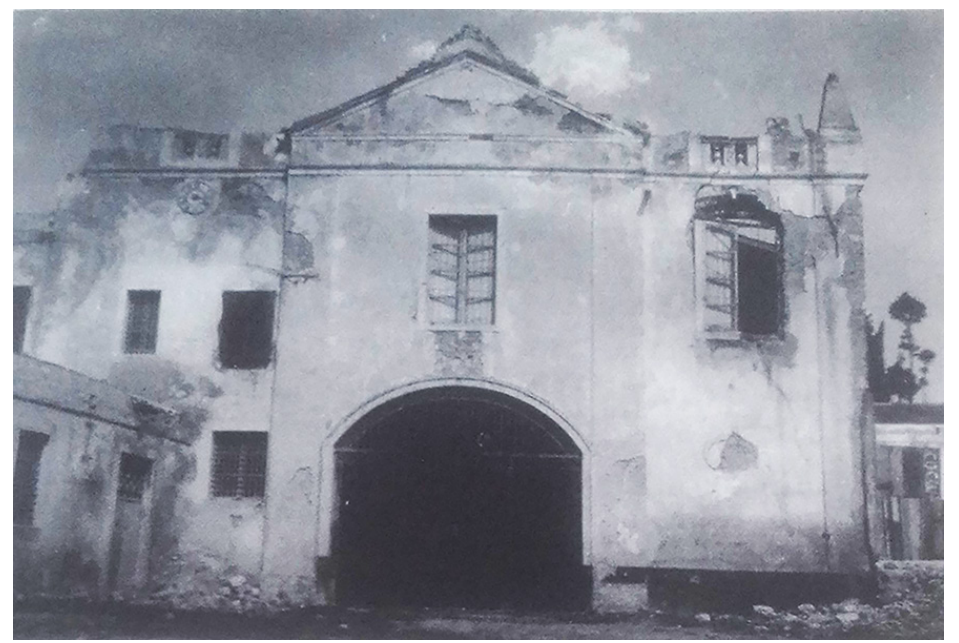

\section{Caravaggio, l'artista della luce}

La lettura critica-interpretativa dell'opera pittorica si concentra fondamentalmente sull'interpretazione dell'artista del luogo, la Sicilia, filtrato il tutto da uno stato d'animo particolare che è quello del fuggiasco [4]. La tela ritrae una stalla di contadini, tipica del paesaggio agricolo della Sicilia del tempo, fatta di elementi che si trovano nella campagna e che l'abile mano dell'uomo ha saputo assemblare per costruire un riparo di fortuna. L'artista, sapiente conoscitore deiVangeli [5], non fa altro che calare la scena della natività di Gesù, nato in una stalla di Betlemme o verosimilmente in una grotta adibita a rifugio per gli animali, in una tipica costruzione rurale. Tipiche sono le tavole non rifinite poste tutte in verticale tranne quella più lunga che fa da trattenuta e crea visivamente un taglio orizzontale tale da contrastare con la scena degli attori disposti lungo una linea obliqua che passa attraverso la Vergine e il Bambino, sino ad uscire fuori dalla tela stessa. La struttura lignea raffigurata, molto simile alla 'paglialora' [6] siciliana, è composta da una semplice tettoia posta al di sopra di un'orditura di pali sormontati da una struttura non ben definita in legno o tela pesante, usata per mantenere il fieno (fig. 4). II dipinto dichiara un passaggio netto tra il Caravaggio giovane, fatto di colori brillanti, e quello 'maturo' che dipinge la realtà nella sua drammatica evidenza e che dà un taglio netto con il suo passato. II rigore delle linee dà ai quadri uno spazio del tutto

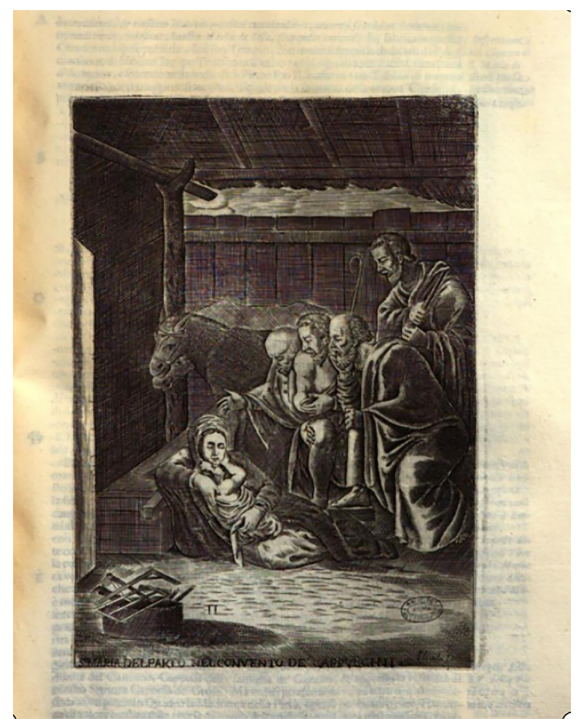

Fig. 3. Placido Donia Madonna del Parto, 1644 (Incisione su Iconologia della Gloriosa Vergine Madre di Dio Maria protettrice di Messina, [Lipar |991, p. 148). 
nuovo, in grado di usare le superfici che talvolta risultano vuote nell'immensità di vaste aree coperte da colori cupi ma della stessa scala cromatica, quasi a seppellire le figure nei colori scuri per farli emergere in fasci di luce. L'opera, certamente, ha risentito fortemente delle caratteristiche geografiche in cui è stata eseguita e il Merisi incentra la struttura pittorica dando alle linee di luce e ai luoghi di penombra delle caratteristiche strettamente fotografiche e geografiche. Nella Adorazione dei pastori, è toccante il modo in cui la luce penetra all'interno della stalla, quella luce calda che è tipica della Sicilia, che segna i volti e le pieghe degli abiti rendendo viva la scena. La bellezza dell'opera sta principalmente nel riscontrare quel chiarore che viene dall'alto e che non lascia intravedere il punto esatto da dove si sprigiona. II raggio luminoso non fa altro che rendere alla tela una superfice tridimensionale unica nel suo genere, facendo cogliere quella caratteristica che coniuga la luce che spacca il silenzio di quell'istante. La ricerca della giusta luce fatta di fasci luminosi radenti che si infrangono su alcune zone di ombra determinano delle linee che cadono su corpi ed oggetti in maniera semplice e naturale. L'osservatore non può fare a meno di calarsi in quella scena rimanendo spettatore silenzioso, tutto attorno è fatto di povertà, tutto attorno vi è un'architettura semplicistica fatta di elementi miseri ma, la cosa che più di tutti dà monumentalità a questo quadro è proprio la luce che grazie alle sue linee attraversa la scena. È il caldo sole messinese che trafigge la stalla, rappresentata da un solido cavo delimitato esclusivamente dai quattro lati. Per due lati troviamo le pareti, quella in legno e quella in muratura, mentre la parte piana della scena è in terra battuta cosparsa di paglia che nella tipicità del luogo prende il nome di 'littera' Infine si scorgono un paniere con del pane poggiato su di una tovaglia e degli attrezzi da lavoro di falegname e, in primissimo piano, un sasso che ha la funzione di creare profondità alla scena e grazie alla parte illuminata e alla sua ombra suggerisce che la luce è proiettata dalla sinistra verso destra.

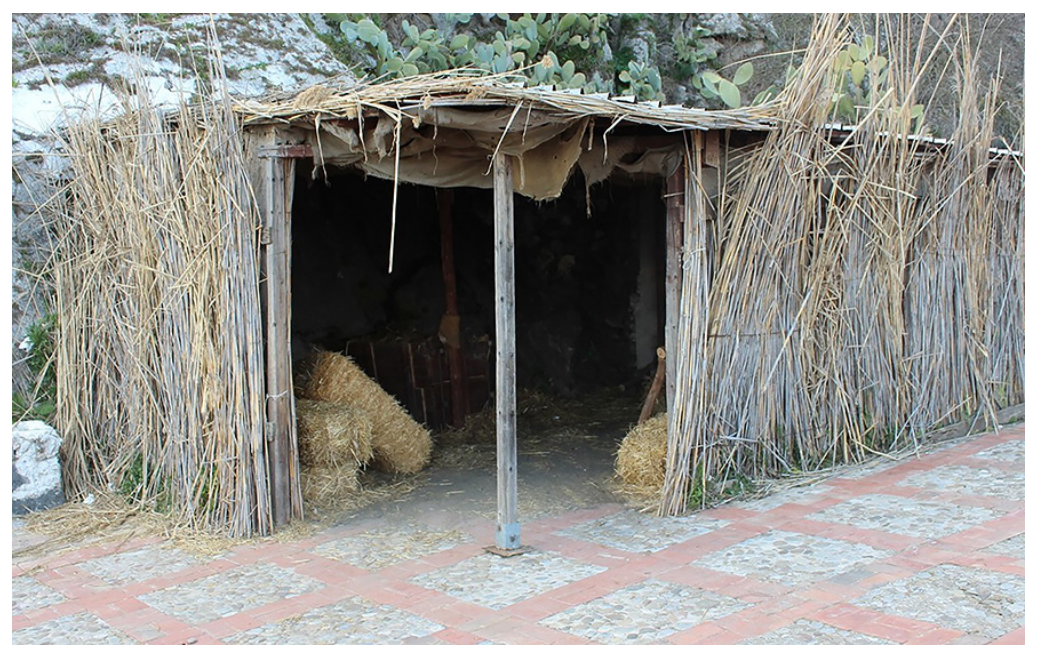

\section{La struttura prospettica e la geometria latente}

Gli studi condotti dalla metà del secolo scorso sul Caravaggio, mettono in luce la figura di un'artista svincolato nelle sue opere da schemi precostituiti e da disegni preparatori. In realtà il Merisi si forma al capezzale dei grandi maestri antesignani del Rinascimento, che abbracciarono quasi due secoli di storia, e proprio grazie a loro riuscirà a cogliere tutte quelle regole di geometria che gli studiosi di tale scienza matematica applicarono in maniera meticolosa nelle loro opere. Dallo studio del dipinto per l'altare della chiesa del convento dei Cappuccini, olio su tela di dimensione $314 \times 21 \mathrm{I} \mathrm{cm}$, si è rilevato uno schema strutturale impostato su rapporti geometrici che regolano e rendono armonica la composizione 
della scena. II Caravaggio struttura l'intera pala dell'altare attraverso rapporti modulari che utilizzano l'unità di misura meridionale - la canna e il palmo - nello specifico napoletani ( I canna $=2,64550 \mathrm{~m}$ e I palmo=0.264550 m). I personaggi sono collocati all'interno di un quadrato di lato pari alla larghezza della pala (palmi $8 \times 0,264=2,112 \mathrm{~m}$ ) e in altezza la tela raggiunge 12 palmi (palmi I $2 \times 0,264=3,168 \mathrm{~m}$ ), (fig. 5). Nelle sue opere pittoriche sono raffigurati personaggi dai tratti noti, non solo per la sua abitudine a rappresentare volti comuni del popolo, ma probabilmente per l'utilizzo di prototipi, di figure già disegnate precedentemente, in cui l'artista aveva ben studiato i rapporti antropometrici. Infatti, da alcune ricerche condotte dagli studiosi Maurizio Bernardelli Curuz e Adriana Conconi Fedrigolli, sembra che l'artista si esercitasse nel disegno dei rapporti antropomorfi, raffigurando figure pronte ad essere usate come riferimento nell'opera dipinta [7]. Tesi avvalorata dal ritrovamento di numerosi disegni nel Fondo della bottega di Peterzano, in cui l'artista svolse il suo apprendistato [8], che pare si ritrovino nelle sue opere note della maturità. II Caravaggio quindi nella sua carriera studia e ripropone rapporti antropometrici che diventano invarianti nelle sue

Fig. 5. Elaborazione grafica. La geometria latente: il modulo regolare ( $12 \times 8$ di palm napoletano).

Fig. 6. Elaborazione grafica. Le regole della prospettiva.
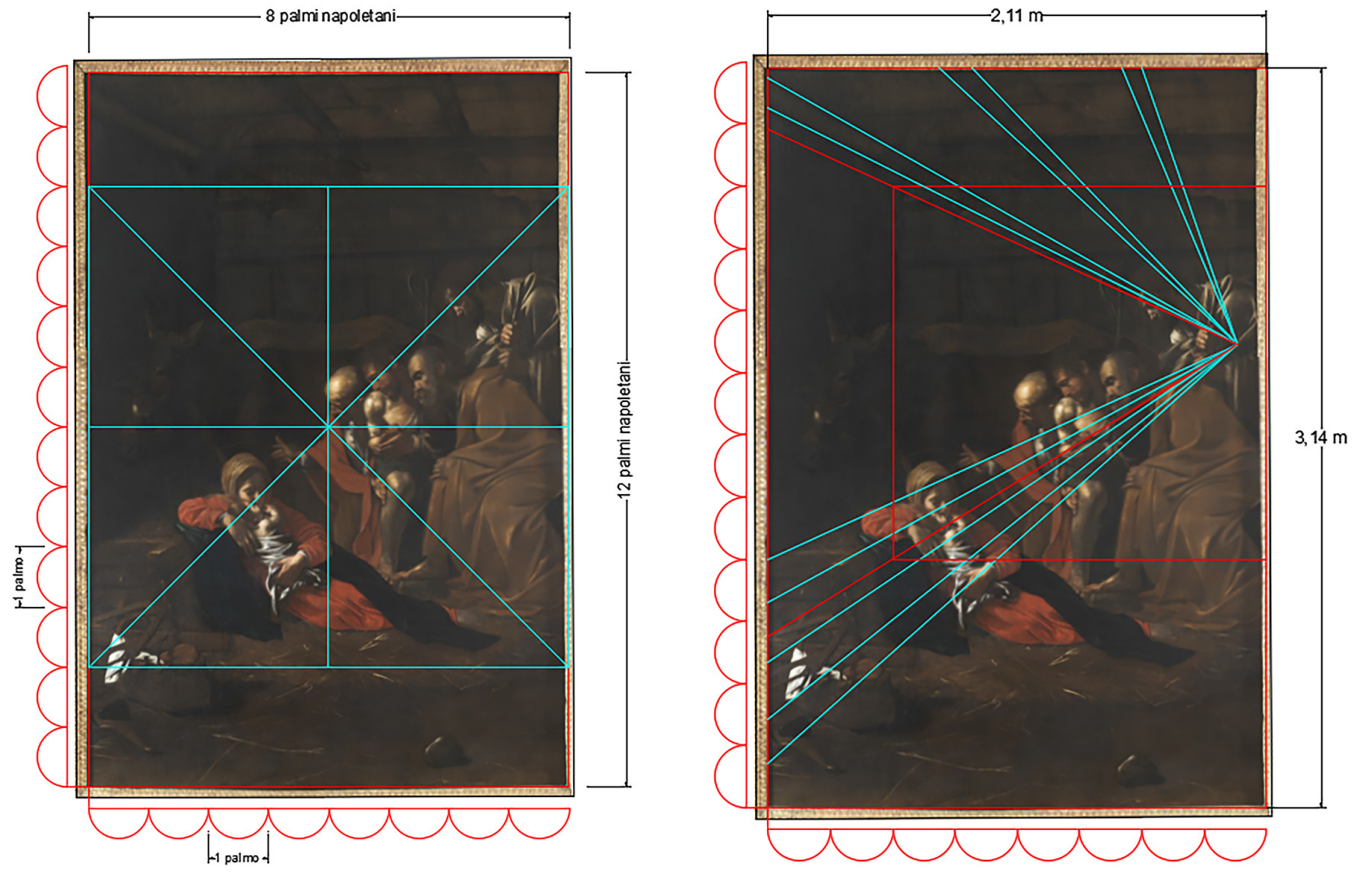

opere, e utilizza il disegno come strumento didattico, preparatorio alla realizzazione dell'opera. Inoltre le incisioni e i segni puntiformi di chiodo o manico di pennello reiterati attorno ai volti, scoperti durante i restauri [Lapucci 1994] del dipinto, avvalorano la tesi che l'artista dipingesse direttamente su tela, seguendo lo schema geometrico, impostato su una matrice strutturale che si presenta ben delineata per stile e tipologia figurativa. II concetto di pittura per Caravaggio è stato incentrato sulla ricerca non solo della luce all'interno della scena, ma anche della 'corretta' prospettiva che tiene conto del punto di vista, attraverso quindi la visione dell'opera d'arte che si lascia apprezzare e ammirare dall'osservatore posto non dovutamente in posizione privilegiata (fig. 6). Nell'Adorazione dei pastori, come affermato nel 1994 da Roberta Lapucci [9] "La complessa costruzione spaziale segue una geometria diagonale impostata sul triangolo rettangolo la cui base è costituita dalla Madonna distesa" [Lapucci 1994] (fig. 7). Tale iconografia trova confronto con le Natività bizantine che presentano la Madonna sdraiata a terra, modello che il Caravaggio avrà sicuramente avuto modo di conoscere durante il soggiorno siciliano. Inoltre i personaggi si allineano lungo l'altra diagonale del quadrato, individuando un secondo triangolo in cui le figure si accavallano, quasi 
a volere lasciare spazio all'invaso architettonico, al capanno semidiroccato che è definito dalla mangiatoia, dalle pareti e dal soffitto della stalla (fig. 8). Inoltre, la suddetta geometria diagonale trova nel simbolo del triangolo l'esaltazione del numero tre. Nella tradizione il triangolo equilatero rappresenta la divinità, l'armonia, la proporzione; di conseguenza il triangolo rettangolo, che è generato dalla suddivisione di questo, corrisponde alla figura umana, al mondo terreno e quindi alla perdita di equilibrio e di armonia. Tale interpretazione è peraltro condivisibile se riferita a un pittore come il Caravaggio, che ebbe una vita molto travagliata, dove il male e il bene che erano in lui non seppero mai integrarsi in una dimensione di pacificazione interiore. II Caravaggio imposta una prospettiva disassata, ponendo i personaggi su un lato della scena e lasciando a vista la profondità della stalla in cui fanno da sfondo l'asinello e il bue. Secondo alcuni studi il Caravaggio dipingeva le sue prospettive con l'aiuto della luce proveniente dall'alto [10] che passava attraverso una lente biconvessa e uno specchio concavo che a sua volta rifletteva direttamente sulla tela l'immagine del soggetto da dipingere. Nell'Adorazione dei pastori, la scelta del punto di vista disassato mette in luce la povertà dell'ambiente e dei materiali, le travi di legno del soffitto, i legni della mangiatoia risultano perfettamente impostati sullo schema prospettico di impianto. La mancanza, purtroppo, di documentazione relativa a elaborati grafici e foto d'epoca degli interni della chiesa, non ha permesso di approfondire le scelte attuate dall'artista nella configurazione della scena prospettica, in relazione al posizionamento della pala sull'altare.

Fig. 7. Elaborazione grafica. La geometria diagonale ed il modulo-griglia

Fig. 8. Elaborazione grafica. I triangoli della luce e dell'ombra
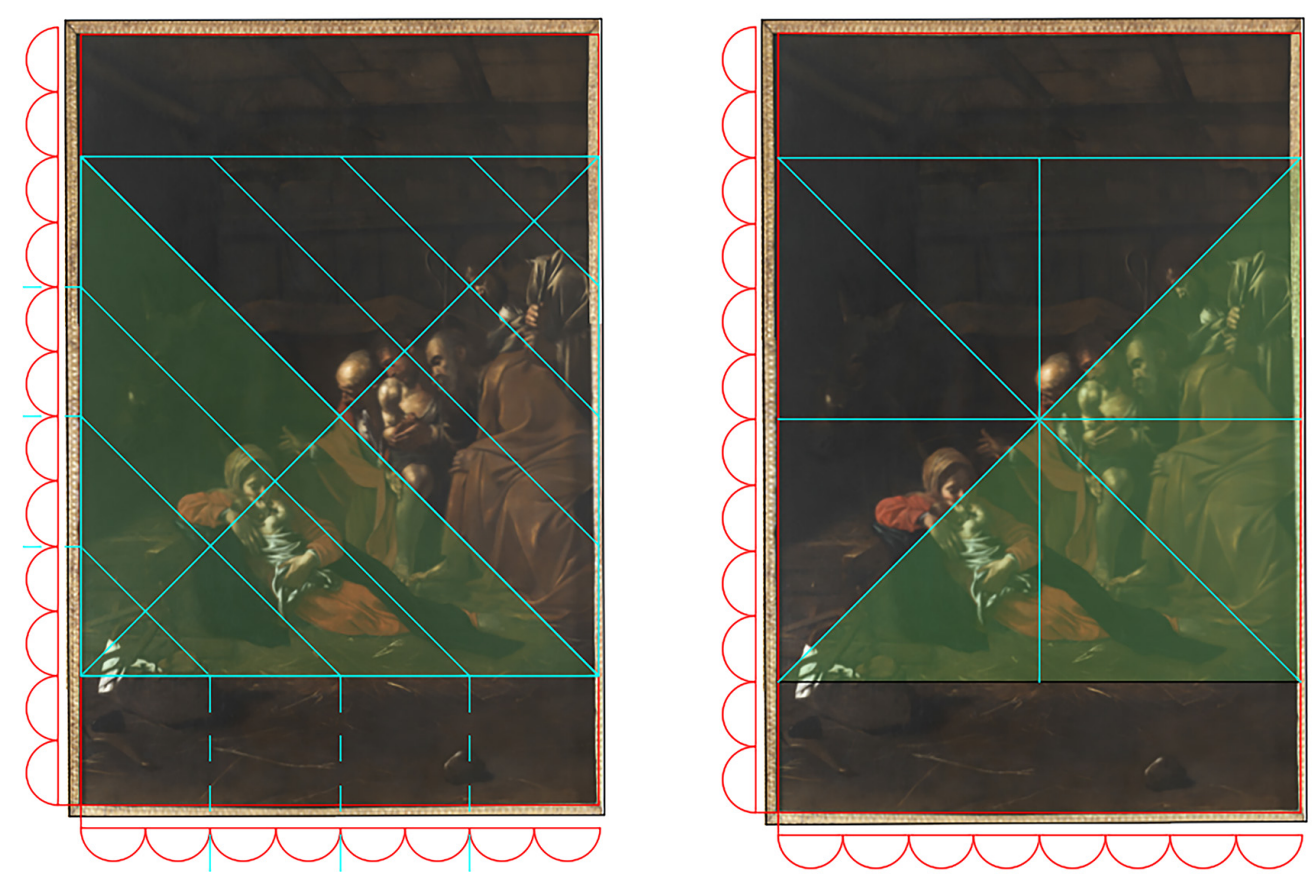

\section{Conclusioni}

Lo studio a posteriori del dipinto del Caravaggio, in assenza di bozzetti preparatori, ha previsto un'analisi dell'opera attraverso lo strumento disvelatore del disegno. Si è indagato a posteriori la possibile struttura compositiva dell'opera e le regole geometriche sottese. II Caravaggio imposta la rappresentazione della pala dell'altare centrale della chiesa francescana utilizzando una prospettiva disassata che conferisce dinamicità alla pacatezza della scena. In questo modo fa emergere la profondità dell'ambiente mettendo in risalto la povertà $\mathrm{e}$ l'umiltà che sono regole della vita monastica dell'ordine dei Cappuccini [ I I ]. 


\section{Note}

[I] Michelangelo Merisi detto Caravaggio (Milano, 28 settembre 1573-Porto Ercole, I 8 luglio |6 I0) è un pittore italiano che imparò l'arte del dipingere, così come testimonia un atto notarile del 6 aprile 1584 come apprendista presso la bottega di Simone Peterzano. Lasciato Milano si recherà a Roma ove dipingerà le sue più importanti opere che segneranno in modo indelebile la pittura italiana di ogni tempo. La sua vita sarà cosparsa di tanti eventi negativi che ne segneranno le scelte prevalentemente fatte di fughe. Commette a Roma un omicidio. Scappa a Napoli e poi di qui a Malta dove entra nell'Ordine dei Cavalieri Gerosolimitani. Con uno di questi il Merisi entrerà in contrasto offendendolo pesantemente tanto da meritare la prigione ma anche qui viene aiutato a fuggire in Sicilia dove rimarrà per poco meno di un anno, dall'ottobre del I608 al settembre dell'anno successivo. Lavorerà a Siracusa e poi Messina ed andrà nuovamente a Napoli. Durante il viaggio di rientro morirà a Porto Ercole colto da una febbre malarica.

[2] II convento dei Cappuccini e l'annessa chiesa di Santa Maria della Concezione sorgevano fuori le mura della città. I frati vi erano stabiliti intorno al I 554 con il sostegno della popolazione e con il favore del vicerè Ettore Pignatelli. Nel I590 notizie riportano la decisione di ampliare il convento e innalzare la chiesa e fare il coro più spazioso. Nel XVII secolo la chiesa intitolata al SS.Salvatore assume l'aspetto planimetrico definitivo e viene dotata di opere d'arte pregiate, tra cui la pala dell'altare maggiore dipinta da Caravaggio. II convento rivestirà nei secoli un ruolo importante per la città sino al terremoto del 1908 che apportò gravi danni alle fabbriche del convento, tanto che nel 1914 si procedette alla demolizione del complesso conventuale divenuto ormai rudere.

[3] Non si conosce l'esatta planimetria della chiesa ma esistono alcune descrizioni di visitatori che vi si recarono nel periodo post unitario, prima che l'edificio venisse spogliato delle sue opere pregiate, a seguito della soppressione delle Corporazioni religiose del 1866, per essere collocate nel I 877 nel Museo Civico e dopo il 1908 il dipinto venne collocato presso il museo regionale Peloritano. L'impianto planimetrico ad unica navata presentava tre cappelle sulla sinistra e tra altari sul lato destro, oltre a oratori per laici sul lato destro e sulla zona presbiteriale. Una sottile parete pare dividesse la zona del coro riservata esclusivamente ai religiosi dall'altare maggiore.

[4] II Merisi scappa da Roma il 28 maggio del 1606 a seguito dell'omicidio di Ranuccio Tommassoni figlio di un ufficiale dello Stato Pontificio. Si rifugia a Malta dove entrerà a far parte dell'Ordine dei Cavalieri Giovanniti, ma la notte del 8 agosto 1608 scoppia una furibonda rissa tra cavalieri e Caravaggio si ripara in Sicilia, aiutato a fuggire dalle prigioni maltesi dai suoi amici.

[5] "È utile sottolineare la forte aderenza del pittore agli assunti cattolici, in particolare tridentini: da giovane respira la profonda spiritualità lombarda che permea la bottega del Peterzano; in più, sedotto dal carattere umano e popolare del Vangelo, Caravaggio è fedele alla vera tradizione del medioevo, che si sforzava di portare la religione cristiana nell'intimità della vita quotidiana [...] II Merisi fu certo un gran peccatore, specie nell'ira, come si sa, ma cattolico peccatore, ben cosciente che gli insegnamenti della Chiesa erano veri" [Radelli 2008].

[6] Nel dialetto siciliano paglialora è una costruzione rurale fatta di materiali poveri, in cui i contadini e gli animali trovavano riparo.

[7] Non si tratta di disegni preparatori ai dipinti, ma di disegni accademici del giovane apprendista, la cui morfologia sarà trasferita nelle opere della maturità, I disegni del periodo di formazione restano infatti "nella mano e nell'occhio" e divengono poi pittura. Specie se vengono ingranditi e trasposti in cartoni.

[8] La presenza di Caravaggio nella Bottega di Peterzano è provata da un inconfutabile documento notarile conservato a Milano, nel quale si registra il contratto tra la madre di Merisi e Peterzano.

[9] Roberta Lapucci, è responsabile del Dipartimento Conservazione Opere d'Arte e di Archeologia dell'Università americana SACI (Studio Art Centers International), con sede a Firenze. Studia come il Caravaggio adottava un sistema di riproduzione dei modelli grazie a lenti e all'utilizzo di una primordiale camera oscura per la visione dell'immagine e con sostanze prevalentemente ottenute dal mercurio si riusciva a impressionare la tela consentendo al pittore di tracciare le linee fondamentali del dipinto. Con le collaborazioni degli istituti scientifici dei Carabinieri sta studiando ancora oggi, grazie a nuove tecnologie di diagnostica un sistema di rilevamento delle impronte digitali del pittore presenti nel dipinto non lasciando più dubbi relativamente alle attribuzioni da parte degli storici dell'arte.

[I0] L'indicazione che il Caravaggio utilizzasse qualche tipo di ottica risale al 1994 quando Roberta Lapucci pubblicò un articolo intitolato Caravaggio e i quadretti nello specchio ritratti a cui fecero seguito Caravaggio e i fenomeni ottici e Caravaggio e l'ottica, pubblicato a Firenze nel 2005.

[I I] Mariateresa Galizia ha scritto i paragrafi: "La struttura geometrica e la geometria latente" e "Conclusioni”; Giuseppe Maria Spera ha scritto i paragrafi:"Introduzione", "Caravaggio, l'artista della luce".

\section{Riferimenti bibliografici}

Abbate Vincenzo (1984). I tempi del Caravaggio. Situazione della pittura in Sicilia (I580- I 625). In AA.VV. Caravaggio in Sicilia: il suo tempo, il suo influsso. Catalogo mostra, Siracusa 1984-1985, pp. 43-76. Palermo: Sellerio.

Baumgart Fritz (1955). Caravaggio: Kunst und Wirklichkeit. Berlin: Mann.

Bellori Giovanni Pietro (1976). Le vite de' pittori, scultori et architetti moderni. Whitefish, Montana: Kessinger Pub Co.

Calvesi Maurizio (1990). Le realtà del Caravaggio. Milano: Einaudi.

Cinotti Mia, Dell'Acqua Gian Alberto (1983). Michelangelo Merisi detto il Caravaggio:Tutte le opere. Bergamo: Poligrafiche Bolis.

Ciolino Maugeri Caterina (1984). Michelangelo Merisi da Caravaggio. Adorazione dei pastori. In Caravaggio in Sicilia: il suo tempo, il suo influsso. Catalogo mostra, Siracusa 1984- 1985. Palermo: Sellerio.

D'Ambrosio Giuseppe A. ( 1685$)$. Quattro portenti della Natura, dell'Arte, della Grazia e della Gloria. Messina: Nella stamperia di Vincenzo d'Amico. 
Friedländer Walter (1955). Caravaggio Studies. Princeton: Princeton Univ Pr.

Gregori Mina (1996). Come dipingeva il Caravaggio. Atti della giornata di studio. Milano: Electa Mondadori.

Grosso Cacopardo Giuseppepe (I 82 I ). Memorie de' pittori messinesi e degli esteri che in Messina fiorirono dal secolo XII al secolo XIX. Messina: Giuseppe Pappalardo.

La Corte Cailler Gaetano (198I). Il Museo Civico di Messina. Catalogo museo. Messina: Pungitopo Editrice.

Lanuzza Stefania (2009). Il convento dei Cappuccini a Messina. In Carolina Miceli, Agostina Passantino (a cura di). Francescanesimo e cultura nella provincia di Messina. Atti del convegno di studio, Messina 6-8 novembre 2008. Palermo: Biblioteca Francescana Officina di Studi medievali.

Lapucci Roberta (1994). Documentazione tecnica sulle opere messinesi del Caravaggio. Come dipingeva il Caravaggio. Le opere messinesi. In Quaderni dell'attività didattica del museo regionale di Messina, n. 4.

Longhi Roberto (195I). Mostra del Caravaggio e dei caravaggeschi. Catalogo mostra, Milano, Palazzo Reale, aprile-giugno I95 I. Milano: Casa Editrice G. C. Sansoni Firenze.

Longhi Roberto (1982). I/ Caravaggio. Roma: Editori Riuniti (Prima edizione 4 dicembre 2006)

Mahon Denis (1951). Addenda to Caravaggio. In The Burlington Magazine. Periodico XCIV, 586, p. 19.

Marini Maurizio (1974). lo Michelangelo da Caravaggio. Roma: Studio B di Bestetti e Bozzi.

Mauceri Enrico (1929). Il Museo Nazionale di Messina. Catalogo museo. Roma: Ministero della Pubblica Istruzione-direzione generale delle belle arti.

Natoli Elvira (1987). I luoghi di Caravaggio a Messina. In L'ultimo Caravaggio e la cultura artistica a Napoli, in Sicilia e a Malta. Siracusa: Ediprint.

Radaelli Enrico Maria (I4 febbraio 2008). Una tela appoggiata ai Vangeli. L'invisibile verità si fa immagine nell'opera del Caravaggio, L'Osservatore Romano, p...

Samperi Placido (1644). Iconologia della Gloriosa Vergine Madre di Dio Maria protettrice di Messina. Messina: Apresso Giacomo Matthei Stampatore Camerale.

Samperi Placido (20 I5). Messana Illustrata. Messina: Palala Press. (Edizione originale 1742)

Sgarbi Vittorio (20 I5). Dal cielo alla terra. Milano: Bompiani.

Susinno Francesco (1960). Le vite de’ pittori messinesi. Firenze: F. Le Monnier.

Vettese Angela, Pinotti Alberto (201 I). Oltre l'immagine. Bergamo: Atlas.

Autori

Mariateresa Galizia, Università di Catania, mgalizia@dau.unict.it

Giuseppe Maria Spera, Universitat de Valencia sgiuma@alumni.uv.es, giusep.spera@tiscali.it

Per citare questo capitolo: Galizia Mariateresa, Spera Giuseppe Maria (2020). Il Caravaggio a Messina e l'Adorazione dei Pastori: una tela da riscoprire/Caravaggio in Messina: the Adoration of the Sheppherds, a canvans to rediscover. In Arena A., Arena M., Brandolino R.G., Colistra D., Ginex G., Mediati D., Nucifora S., Raffa P. (a cura di). Connettere. Un disegno per annodare e tessere. Atti del $42^{\circ}$ Convegno Internazionale dei Docenti delle Discipline della Rappresentazione/Connecting. Drawing for weaving relationships. Proceedings of the 42th International Conference of Representation Disciplines Teachers. Milano: FrancoAngeli, pp. 3313-3328. 


\title{
Caravaggio in Messina: The Adoration of the Shepherds, a Canvans to Rediscover
}

\author{
Mariateresa Galizia \\ Giuseppe Maria Spera
}

Abstract

This research examines the work of the great Michelangelo Merisi, or Caravaggio, created during his stay in Sicily. The painting was commissioned by the Senate of Messina and then donated to the Capuchin Franciscan friars to decorate the high altar of the church of Santa Maria la Concezione of the Capuchin convent. Today, it is preserved in the Regional Museum of the city. The iconography in the painting is Franciscan and a critical, a posteriori reading of the work (without any preliminary sketches) immediately reveals Caravaggio's sensitivity to the emotions that the places he resided in were able to provoke in his restless personality. The artist's attention to the customs and traditions of the local people is veiled by the mournful atmosphere that pervades his later works. In his scenes, Caravaggio reinterprets local customs, traditions and materials, such as the Sicilian 'paglialore', and associates them with matters of universal significance. Design analysis of the painting suggests that the artist used underlying geometrical guide lines to arrange the represented scene in the southern cane and palm units of measurement. Further analysis of the main perspective suggests he used an offset to provide depth and more space to the scene, allowing greater clarity for the characters inside it.

Keywords

Michelangelo Merisi, realism, light, perspective, regulatory tracks.

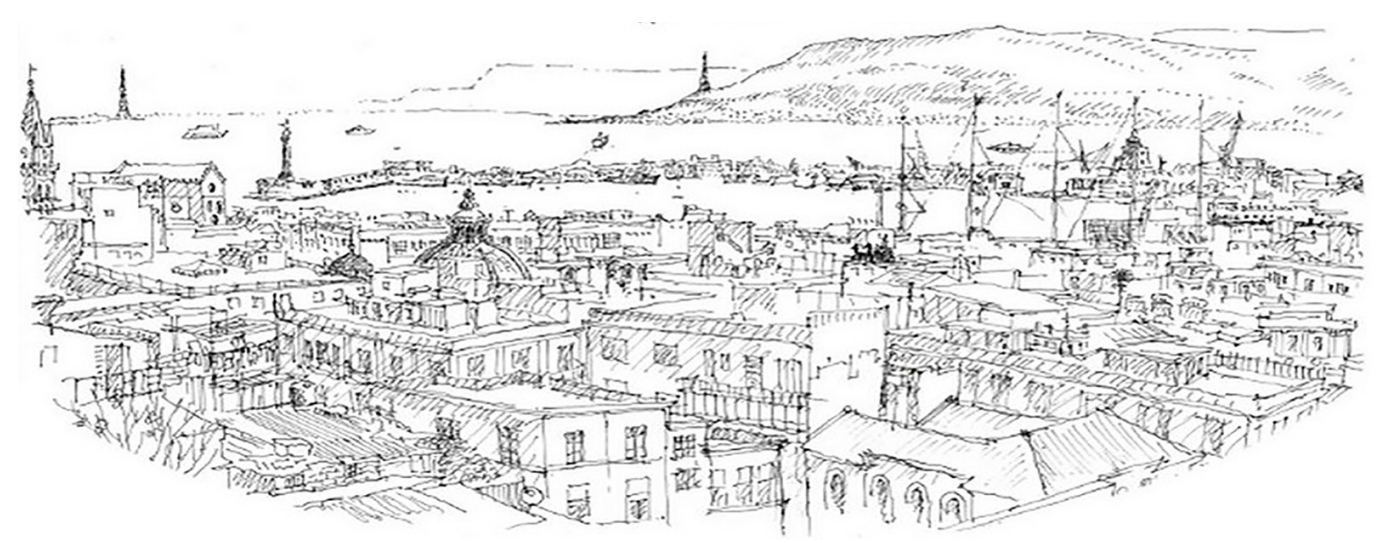




\section{Introduction}

Over the centuries, the Strait of Messina has inspired stories, myths and legends, and has witnessed countless encounters with foreign civilizations that have implanted their knowledge in the customs and traditions of the local Sicilian inhabitants. The consistent attention of the ancient Greek, Roman, Arab, Norman and Spanish civilizations and the numerous historical figures that have travelled around Sicily have forged a multicultural region out of the strait and of the island. During his stay in Sicily, Michelangelo Merisi [I], known as Caravaggio, would have experienced sounds, smells, tastes, lights, shadows and colours of surroundings and landscapes that differed significantly from those he left behind in Rome and Malta. Famous for his unprejudiced depictions of daily life, real environments and common people, the artist drew inspiration for his pictorial scenes from the earthy materials, traditions and customs of the island. Adoration of the Shepherds is one of two pieces created by Caravaggio in the city of Messina (fig. I). The work represents the Nativity of the poor in a reinterpretation that connects and combines the emotions evoked by his surroundings and his experiences. The painting was commissioned in 1609 by the Senate of Messina to adorn the high altar of the Church of Santa Maria la Concezione [2], run by Capuchin Franciscan monks no longer exist today [3] (fig. 2). The painter had repeated contacts with the religious order, which were strengthened and rekindled during the various stages of his residence in Sicily through an intense vision of communal spirit and intent (fig. 3).

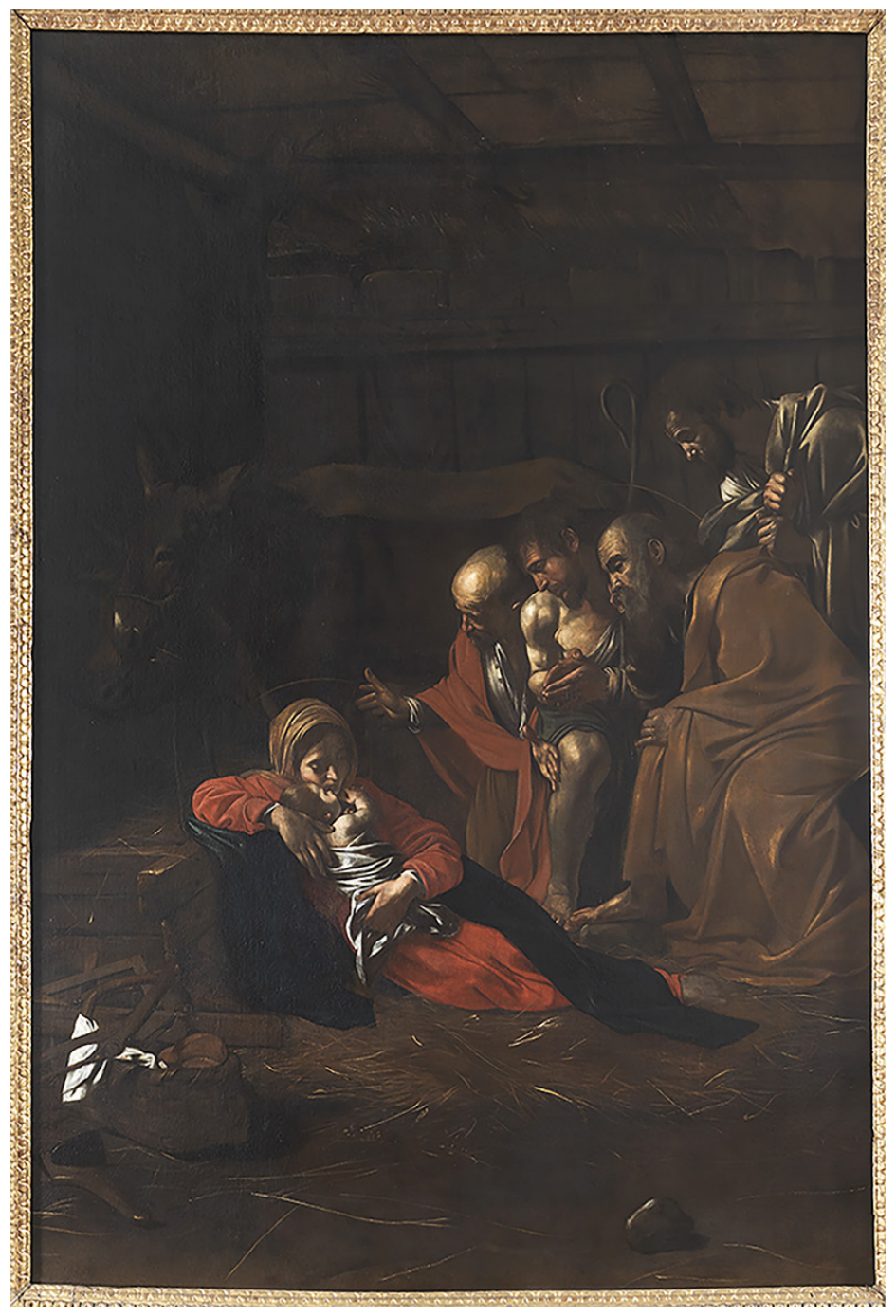


Fig. 2. Prospectus of the Capuchin Church after the earthquake of 1908 G. Molonia, Opere d'arte dei Cappuccini di Messina, edited by G. Lipari, Messina 2015, p. 239

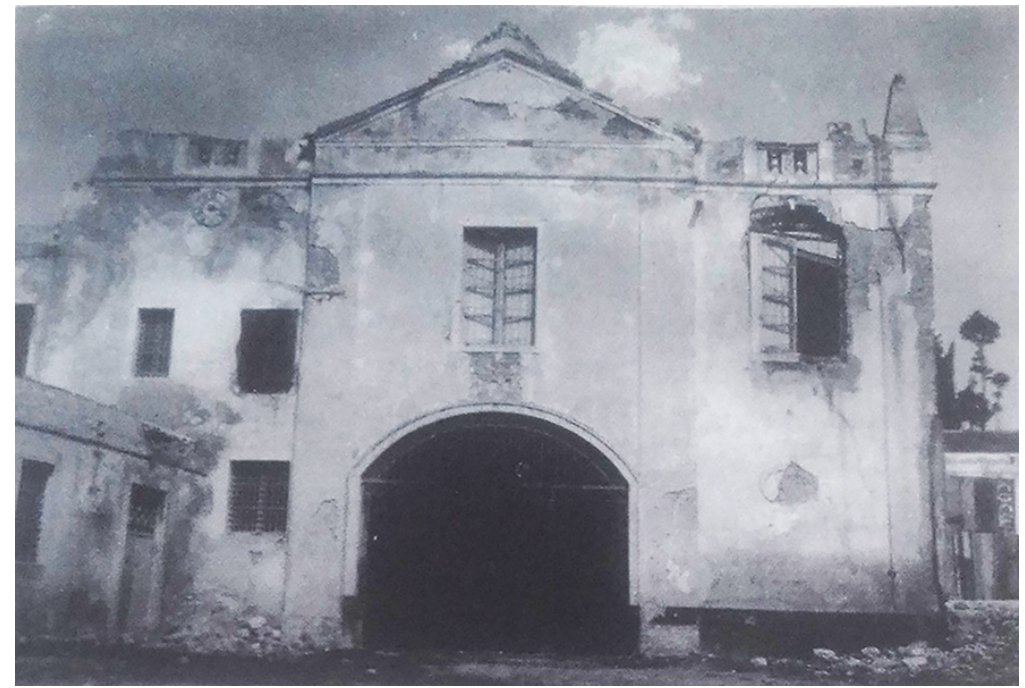

\section{Caravaggio, the artist of light}

Critical interpretation of the pictorial work primarily focuses on the artist's interpretation of the location, Sicily, through his fugitive disposition or state of mind [4]. The canvas depicts a peasant's stable, typical of agricultural Sicily at the time, consisting of ordinary local materials used to create rudimentary shelters. The artist, well versed in the Gospels [5], faithfully recreates the rural setting of the Nativity of Jesus, who was born in a stable in Bethlehem or perhaps in a cave used as a shelter for animals. The untreated boards are all placed vertically, except for a longer horizontal beam that contrasts the oblique arrangement of the protagonists in a line that passes through the Virgin and Child to the extents of the canvas. The structure is reminiscent of the Sicilian 'paglialora' [6] with a simple canopy on a pole frame surmounted by an undefined structure in wood or heavy canvas to hold the hay (fig. 4). The painting clearly marks a break from the young Caravaggio of bright colours to the more mature artist who places reality in dramatic evidence. The lines create completely new spaces often involving empty surfaces in vast regions of dark colours in the same chromatic scale, as if to allow the figures to emerge from the buried depths on beams of light. The work was certainly influenced deeply by the geographical characteristics where it was created

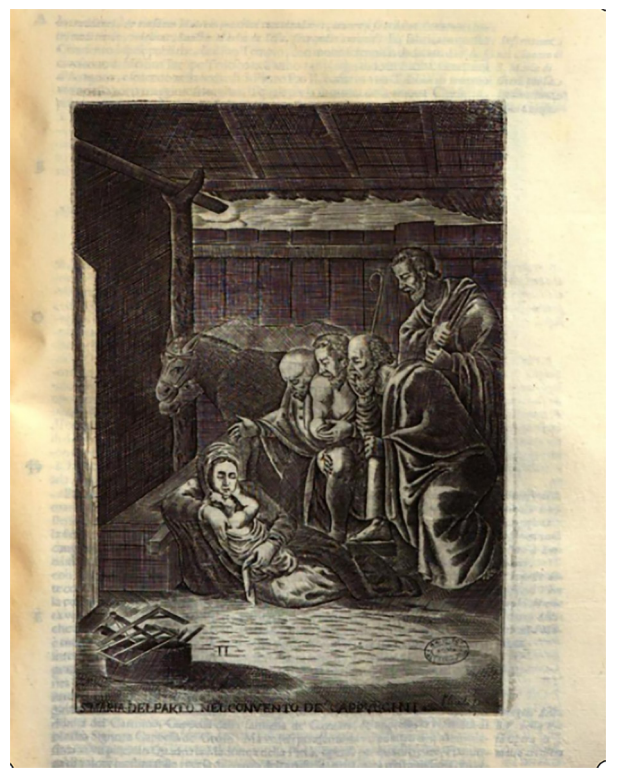

Fig. 3. Placid Donia, Ma donna del Parto, 1644. (Engraving on Iconologia della Gloriosa Vergine tettrice di Messina [lipa 199|, p. |48] 
and Merisi focuses the pictorial structure with the strictly photographic and geographical characteristics of the lines of light and regions of semi shade. The warm light, for which Sicily is renowned, brings the Adoration of the Shepherds scene to life as it penetrates the stable and splashes across faces and folds of clothing. This beautiful light from above, of which no indication of its source is given, renders the canvas a unique three-dimensional surface that captures the instant in which it breaks the silence. Searching beams of light break on shaded regions and fall on bodies and objects along simple and natural lines. The observer can only enter the scene as a silent spectator surrounded by poverty and simplistic architecture built from meagre resources, but is nonetheless awed by the lines of light traversing the scene. The warm sunlight of Messina pierces the barn in a solid cable delimited only by the four sides. On two sides we find the wooden and masonry walls, while the flat beaten earth is sprinkled with straw, locally referred to as 'littera'. Finally we can see a basket with bread lying on a tablecloth, carpenter's tools and a stone in the foreground that provides depth to the scene and evidence of the direction of the incoming light from left to right.

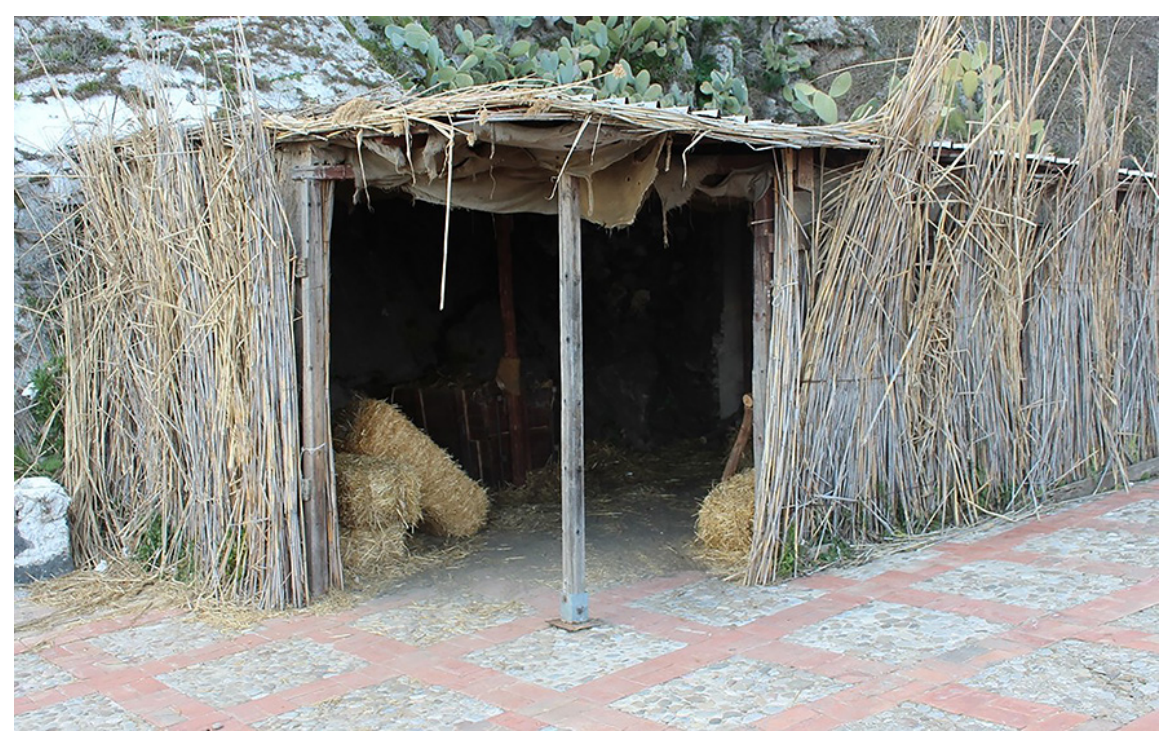

\section{The perspective structure and latent geometry}

Studies on Caravaggio since the middle of the last century speak of an artist who is not bound by pre-constructed schemes and preparatory drawings. Actually, Merisi's careful study of the great masters across two centuries of the Renaissance gave him firm grasp of the rules of geometry that scholars of this mathematical science applied meticulously in their work. The study of the oil on canvas painting measuring $314 \times 21 I \mathrm{~cm}$ for the altar of the church of the Capuchin convent revealed a structural scheme based on geometrical ratios that regulate and harmonize the composition of the scene. Caravaggio structures the entire altarpiece through modular ratios using the Neapolitan cane and palm units of measurement ( $\mathrm{I}$ cane $=2.64550 \mathrm{~m}$ and I palm=0.264550 m) used in the South. The characters occupy a square of sides equal to the width of the altarpiece (palms $8 \times 0.264$ $=2.112 \mathrm{~m}$ ) and the canvas reaches 12 palms (palms I $2 \times 0.264=3.168 \mathrm{~m}$ ) in height (fig. 5). His pictorial works involve characters with recurring features, not only for his desire to represent the faces of common people, but also probably due to his use of prototype figures he had already drawn and was therefore familiar with their anthropometric relationships. Research conducted by Maurizio Bernardelli Curuz and Adriana Conconi Fedrigolli indeed suggests that the artist practiced drawing anthropomorphic relationships, depicting figures to be used for reference in his paintings [7]. This thesis is supported by 
the discovery of numerous drawings in the care of Fondo della bottega di Peterzano where the artist completed his apprenticeship [8], which seem appear in his known later works. Caravaggio therefore studied and proposed anthropometric relationships that invariably found their way into his paintings, and used drawing as a didactic tool in preparation of new work. In addition, the engravings and punctiform nail or brush handle marks repeated around the faces discovered during the restoration [Lapucci 1994] of the painting confirm that the artist painted directly on canvas according to the geometric scheme set on a well-defined structural matrix in terms of style and figurative type. The concept of painting for Caravaggio was centred not only on the exploration of light throughout the scene, but also on a conviction that art should also be appreciated and admired by a less privileged audience (fig. 6). In the Adoration of the Shepherds, Roberta Lapucci in 1994 [9] states "The complex spatial construction follows a diagonal geometry set on the rectangular triangle whose base is the lying Madonna" [Lapucci 1994] (fig. 7). This icono-

Fig. 5. Graphic processing The latent geometry: the regular module ( $12 \times 8$ of Neapolitan palm).

Fig. 6. Graphic processing The rules of perspective.
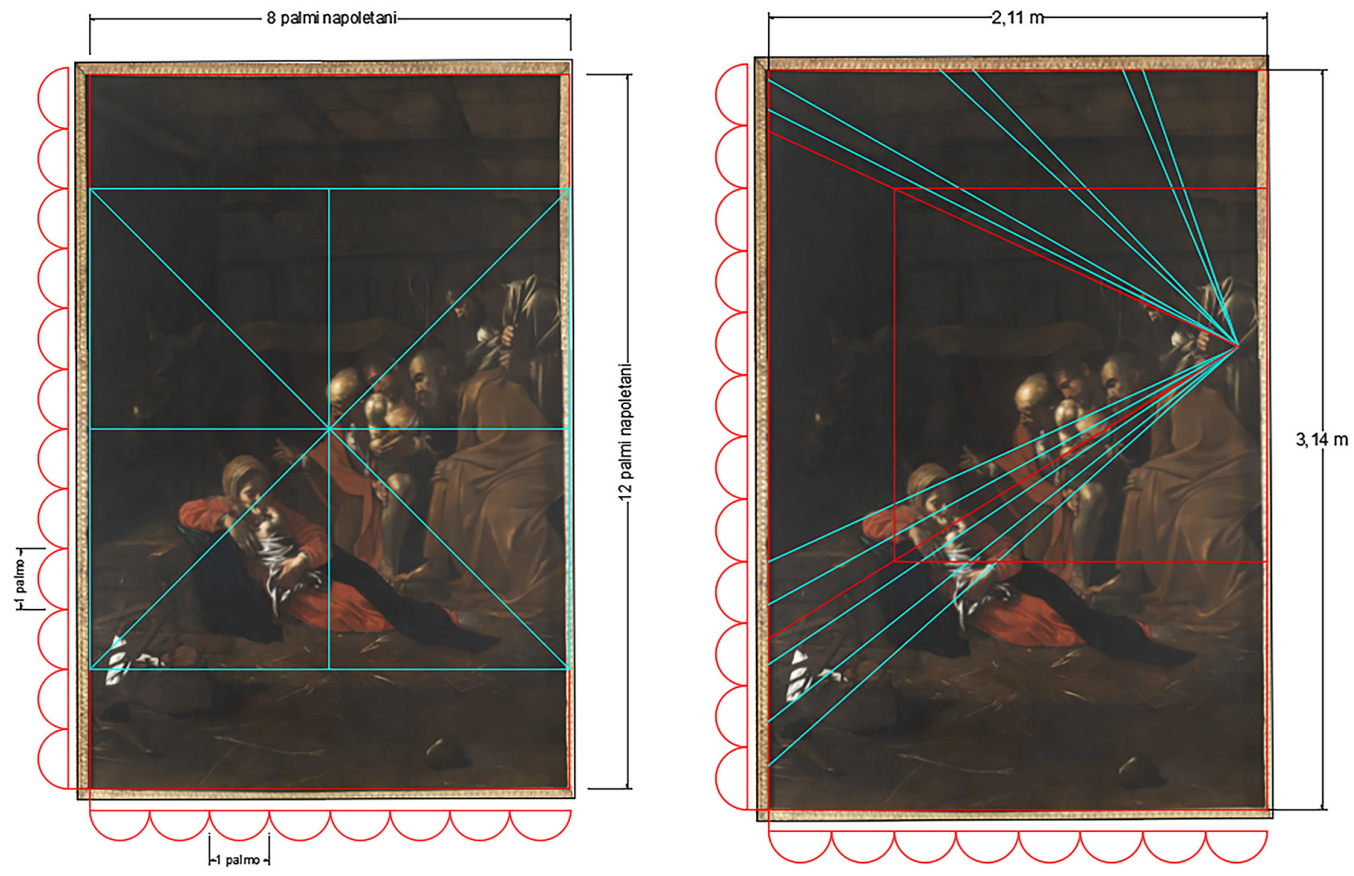

graphy is compared with Byzantine Nativity scenes that present the Madonna lying on the ground, a model that Caravaggio must have aware of during his stay in Sicily. In addition, the characters are aligned along the other diagonal of the square to form a second triangle in which the figures overlap, almost as if to make room for the architectural invasion of the semi-detached hut defined by the walls and ceiling of the manger. This diagonal geometry, by its triangularity, also exalts the number three (fig. 8). While the equilateral triangle traditionally represents divinity, harmony and proportion, the rectangular triangle generated from its subdivision must therefore represent the human figure consequently bound to the imbalances and disharmony of the earthly realm. This might be especially applicable to a painter like Caravaggio, whose troubled life never found peaceful integration between his inner good and evil dimensions. Caravaggio sets an offset perspective, locating the characters to one side of the scene and leaving the barn animals in the background. According to some studies, Caravaggio painted his perspectives using light from above [10] passed through a biconvex lens, and a concave mirror to reflect the subject's 
image directly onto the canvas. In Adoration of the Shepherds, the offset perspective highlights the poverty of the environment and the materials; the ceiling beams and the wooden manger are perfectly set in the perspective of the scene. Unfortunately, the lack of graphic or documentary evidence regarding the interior of the church when the painting was commissioned does not allow deeper analysis of how the orientation of the altarpiece on the altar may have influenced the artist's decisions associated with the perspective.

\section{Conclusion}

The a posteriori study of Caravaggio's painting, in the absence of any preparatory sketches, was based on a design analysis of the painting to investigate the possible compositional structure of the work, including any underlying geometric sketches. Caravaggio set the representation of the central altarpiece of the Franciscan church using an offset perspective that animates an otherwise mute scene. His technique allows the depth of the setting to emerge and reinforces the underlying poverty and humility that characterizes the monastic life of the Capuchin order.

Fig. 7. Graphic processing Diagonal geometry and grid modulus.

Fig. 8. Graphic processing The triangles of light and shadow.
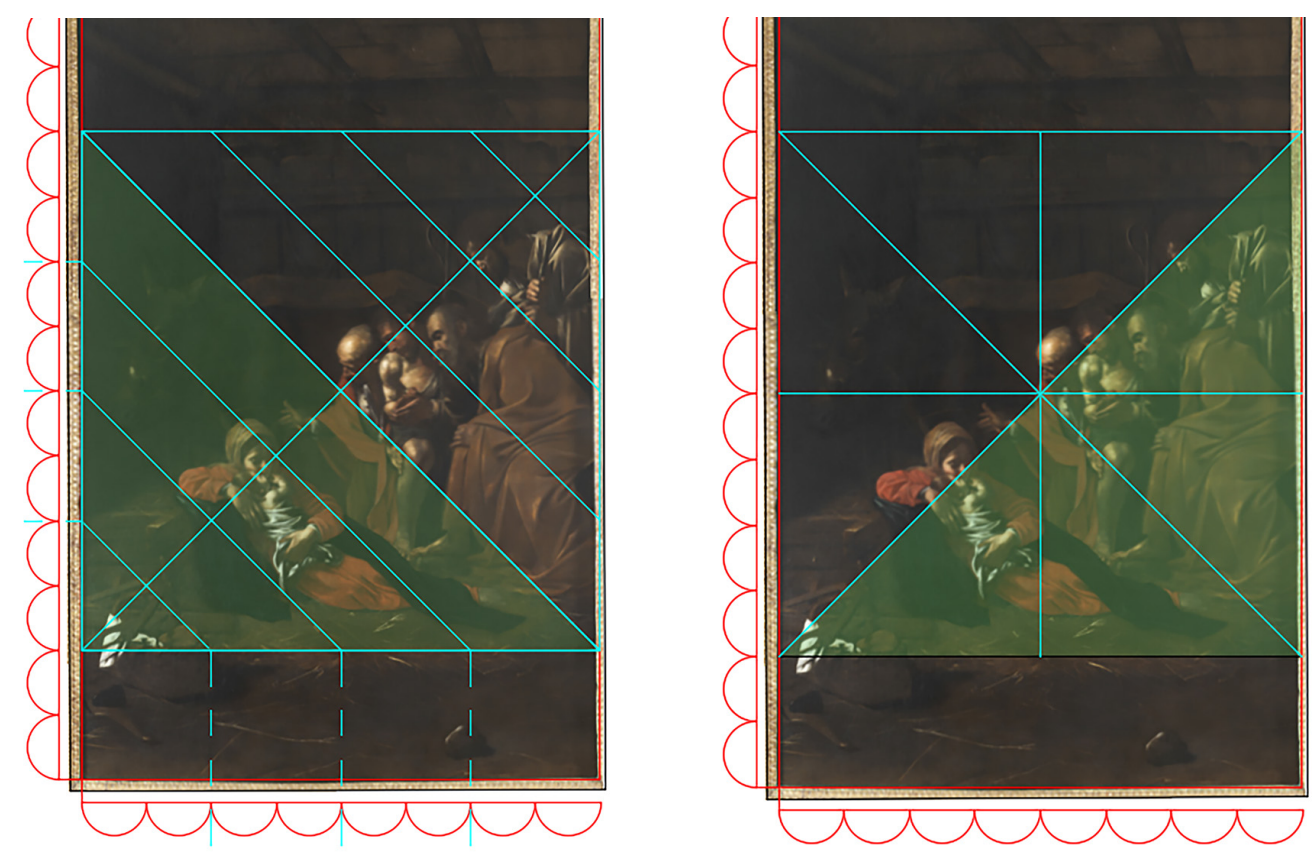

\section{Notes}

[I] Michelangelo Merisi known as Caravaggio (Milan, 28 September 1573 - Porto Ercole, I8 July I6I0) is an Italian painter who learned the art of painting, as evidenced by a notarial deed dated 6 April 1584 as an apprentice in Simone Peterzano's workshop. After leaving Milan, he went to Rome where he painted his most important works that would forever mark the Italian painting landscape. His life was marred by numerous negative events that shape his frequent escapes from one city to another. He commits a murder in Rome and escapes to Naples and then to Malta, where he enters the Order of the Knights Hospitaller. Merisi avoids prison after heavily offending one of the knights of the order by escaping to Sicily, where he remains from October 1608 to September of the following year. He worked in Syracuse and then Messina. He died on his journey back to Naples in Porto Ercole after contracting malaria.

[2] The Capuchin convent and the adjoining church of Santa Maria della Concezione stood outside the city walls. The friars established themselves there around 1554 with the support of the population and with the favour of Viceroy Ettore Pignatelli. In 1590 came the decision to expand the convent, raise the church and make the choir more spacious. In the XVII century, 
the church dedicated to the Holy Savior took on its definitive planimetric aspect and was equipped with valuable works of art, including the altarpiece of the high altar painted by Caravaggio. Over the centuries, the convent played an important role for the city until the earthquake of 1908, which caused serious damage to the convent's factories, so much so that the complex was demolished into a ruin in 1914 .

[3] The exact plan of the church is not known, but there are some descriptions by visitors there in the post-unification period, before the building was robbed of its valuable works, following the suppression of the religious guilds in I866, to be placed in 1877 in the Civic Museum, and after 1908, the painting was placed in the Peloritano Regional Museum. The single nave plan had three chapels on the left and between altars on the right side, as well as lay oratories on the right side and the presbyterial area. A thin wall seems to have divided the choir area reserved exclusively for the religious from the high altar (cf. Stefania Lanuzza, II convento dei Cappuccini a Messina, edited by Carolina Miceli and Agostina Passantino, Francescanesimo e cultura nella provincia di Messina, Atti del convegno di studio, Messina 6-8 November 2008, Biblioteca Francescana Officina di Studi medievali , Palermo 2009.

[4] Merisi escaped from Rome on 28th May 1606 following the murder of Ranuccio Tommassoni, son of an officer of the Papal States. He sought refuge in Malta, but a furious brawl involving the knights resulted in Caravaggio having to take refuge in Sicily after escaping from prison with the help of friends.

[5] "With Caravaggio, the Church is the first to trigger the problem of "defect", in other words evil, in art: it was born from the relationship among 'intelligence' (therefore 'freedom'), 'nature' (therefore perhaps 'sin') and 'grace' (therefore God); the Church is the first and only social community to solve it positively [...] It is useful to underline the strong adherence of the painter to the Catholic assumptions, especially the Tridentine: as a young man he has breathed the deep Lombard spirituality that permeates the workshop of Peterzano; in addition, seduced by the human and popular character of the Gospel, Caravaggio is faithful to the true tradition of the Middle Ages, which endeavoured to bring the Christian religion to the intimacy of everyday life. We know that Merisi was certainly a great sinner, especially in anger, but he was a Catholic sinner who remained faithful to the teachings of the Church" [Radelli 2008].

[6] In Sicilian dialect 'pagliolora' is a rural construction made of poor materials, in which farmers and animals found shelter

[7] These are not preparatory drawings for the paintings, but academic drawings of the young apprentice, whose morphology will be transferred to the works of his maturity. The drawings of the training period remain "in the hand and eye" and then become paintings, especially if they are enlarged and transposed into cartoons.

[8] Caravaggio's presence in the Bottega di Peterzano is proved by an irrefutable notarial document kept in Milan, in which the contract between Merisi's mother and Peterzano is recorded.

[9] Roberta Lapucci, is the head of the Department of Conservation of Works of Art and Archaeology of the American University SACI (Studio Art Centers International), based in Florence. She studies how Caravaggio adopted a system of mode reproduction using lenses and the use of a rudimentary darkroom for the vision of the image. Using substances mainly derived from mercury, it was possible to impress the canvas allowing the painter to trace the fundamental lines of the painting. With the collaboration of the scientific institutes of the Carabinieri she is studying new diagnostic technologies for taking painters fingerprints from their painting in order to remove doubts regarding authenticity.

[10]The notion that Caravaggio may have used optics dates back to 1994 when Roberta Lapucci published an article entitled Caravaggio e i quadretti nello specchio ritratti followed by Caravaggio e i fenomeni ottici and Caravaggio e l'ottica, published in Florence in 2005.

\section{References}

Abbate Vincenzo (1984). I tempi del Caravaggio. Situazione della pittura in Sicilia (I 580- 1625). In AA. WV. Caravaggio in Sicilia: il suo tempo, il suo influsso. Catalogo mostra, Siracusa 1984-1985, pp. 43-76. Palermo: Sellerio.

Baumgart Fritz (1955). Caravaggio: Kunst und Wirklichkeit. Berlin: Mann.

Bellori Giovanni Pietro (1976). Le vite de' pittori, scultori et architetti moderni. Whitefish, Montana: Kessinger Pub Co.

Calvesi Maurizio (1990). Le realtà del Caravaggio. Milano: Einaudi.

Cinotti Mia, Dell'Acqua Gian Alberto (1983). Michelangelo Merisi detto il Caravaggio:Tutte le opere. Bergamo: Poligrafiche Bolis.

Ciolino Maugeri Caterina (1 984). Michelangelo Merisi da Caravaggio. Adorazione dei pastori. In Caravaggio in Sicilia: il suo tempo, il suo influsso. Catalogo mostra, Siracusa 1984-1985. Palermo: Sellerio.

D’Ambrosio Giuseppe A. (1685). Quattro portenti della Natura, dell'Arte, della Grazia e della Gloria. Messina: Nella stamperia di Vincenzo d'Amico.

Friedländer Walter (1955). Caravaggio Studies. Princeton: Princeton Univ Pr.

Gregori Mina (1996). Come dipingeva il Caravaggio. Atti della giornata di studio. Milano: Electa Mondadori.

Grosso Cacopardo Giuseppe (| 82 I). Memorie de' pittori messinesi e degli esteri che in Messina fiorirono dal secolo XII al secolo XIX. Messina: Giuseppe Pappalardo.

La Corte Cailler Gaetano (198I). Il Museo Civico di Messina. Catalogo museo. Messina: Pungitopo Editrice.

Lanuzza Stefania (2009). Il convento dei Cappuccini a Messina. In Carolina Miceli, Agostina Passantino (a cura di). Francescanesimo e cultura nella provincia di Messina. Atti del convegno di studio, Messina 6-8 novembre 2008. Palermo: Biblioteca Francescana Officina di Studi medievali.

Lapucci Roberta (1994). Documentazione tecnica sulle opere messinesi del Caravaggio. Come dipingeva il Caravaggio. Le opere messinesi. In Quaderni dell'attività didattica del museo regionale di Messina, n. 4. 
Longhi Roberto (195 I). Mostra del Caravaggio e dei caravaggeschi. Catalogo mostra, Milano, Palazzo Reale, aprile-giugno I95 I. Milano: Casa Editrice G. C. Sansoni Firenze.

Longhi Roberto (1982). I/ Caravaggio. Roma: Editori Riuniti (Prima edizione 4 dicembre 2006).

Mahon Denis (195I). Addenda to Caravaggio. In The Burlington Magazine. Periodico XCIV, 586, p. 19

Marini Maurizio (1974). lo Michelangelo da Caravaggio. Roma: Studio B di Bestetti e Bozzi.

Mauceri Enrico (1929). II Museo Nazionale di Messina. Catalogo museo. Roma: Ministero della Pubblica Istruzione-direzione generale delle belle arti.

Natoli Elvira (1987). I luoghi di Caravaggio a Messina. In L'ultimo Caravaggio e la cultura artistica a Napoli, in Sicilia e a Malta. Siracusa: Ediprint.

Radaelli Enrico Maria (I 4 febbraio 2008). Una tela appoggiata ai Vangeli. L'invisibile verità si fa immagine nell'opera del Caravaggio, L'Osservatore Romano, p....

Samperi Placido (1 644). Iconologia della Gloriosa Vergine Madre di Dio Maria protettrice di Messina. Messina: Apresso Giacomo Matthei Stampatore Camerale.

Samperi Placido (20I5). Messana Illustrata. Messina: Palala Press. (Edizione originale 1742).

Sgarbi Vittorio (20 I5). Dal cielo alla terra. Milano: Bompiani.

Susinno Francesco (1960). Le vite de' pittori messinesi. Firenze: F. Le Monnier.

Vettese Angela, Pinotti Alberto (201 I). Oltre l'immagine. Bergamo: Atlas.

\section{Authors}

Mariateresa Galizia, Università di Catania, mgalizia@dau.unict.it

Giuseppe Spera, Universitat de Valencia, sgiuma@alumni.uv.es, giusep.spera@tiscali.it

To cite this chapter. Galizia Mariateresa, Spera Giuseppe (2020). II Caravaggio a Messina e l'Adorazione dei Pastori: una tela da riscoprire/Caravaggio in Messina: the Adoration of the Sheppherds, a canvans to rediscover. In Arena A., Arena M., Brandolino R.G., Colistra D., Ginex G., Mediati D., Nucifora S., Raffa P. (a cura di). Connettere. Un disegno per annodare e tessere. Atti del $42^{\circ}$ Convegno Internazionale dei Docenti delle Discipline della Rappresentazione/Connecting. Drawing for weaving relationships. Proceedings of the 42 th International Conference of Representation Disciplines Teachers. Milano: FrancoAngeli, pp. 3313-3328. 